\title{
ANANLISIS PENGENALAN LAGU ANAK-ANAK SECARA GRAFIS ATAU MULTIMEDIA
}

\author{
Rahma Latifa $^{1)}$, Tita Syavira ${ }^{2)}$ \\ Program Studi Desain Komunikasi Visual, Universitas Indraprasta PGRI \\ Email: rahmalatifa31@gmail.com
}

\begin{abstract}
Abstrak
Pada era modern ini hampir segala sesuatu sudah menggunakan teknologi digital, bahkan hampir semua kalangan menggunakan gadget. Seperti hal nya Youtube yang saat ini menjadi media berbagi video yang banyak diminati. Oleh karena itu, penulisan ini bertujuan untuk memberikan informasi pembelajaran yang saat ini sangat efektif untuk pengenalan lagu-lagu yaitu dengan pengenalan lagu anak-anak secara grafis atau multimedia yang dapat diakses melalui Youtube. Lagu anak-anak dengan menggunakan grafis digital, tentu sangat efektif dalam pembelajaran, karena pendidikan karakter juga dapat disatukan dengan bernyanyi melalui syair atau lirik lagu. Penulisan ini menggunakan pendekatan kualitatif, yaitu dengan pengumpulan data dari beberapa artikel dan buku. Hasil penelitian penulis yaitu menjelaskan apa saja yang terkandung dalam video dan lirik secara grafis dan penulisan ini mendapatkan fakta bahwa lagu anak-anak yang divisualisasikan dengan grafis sangat diminati pada era sekarang ini.
\end{abstract}

Kata Kunci: Lagu Anak-anak, Grafis, Multimedia

\begin{abstract}
In this modern era almost everything already uses digital technology, in fact almost all circles use gadgets. Like YouTube, which is currently the most popular video sharing media. Therefore, this writing aims to provide learning information which is currently very effective for the introduction of songs by introducing graphically or multimedia children's songs that can be accessed via Youtube. Children's songs using digital graphics are certainly very effective in learning, because character education can also be put together by singing through poetry or song lyrics. This writing uses a qualitative approach, namely by collecting data from several articles and books. The author's research results, namely explaining what is contained in the video and lyrics graphically and writing, get the fact that children's songs visualized with graphics are very popular in today's era.
\end{abstract}

Keywords: Children Songs, Graphic, Multimedia

Correspondence author: Rahma Latifa, rahmalatifa31@gmail.com, Jakarta, and Indonesia 


\section{PENDAHULUAN}

Pada sistem pembelajaran yang lebih inovatif dan interaktif, informasi yang diberikan oleh pengajar ditunutut untuk kreatif inovatif dalam mencari pembelajaran yang mampu menggabungkan antara teks, gambar, audio, musik, animasi gambar atau video dalam satu kesatuan guna untuk menciptakan sesuatu yang baru yang bertujuan pembelajaran dapat sampai dan juga dapat menimbulkan rasa senang dan nyaman saat proses belajar berlangsung (Purnama 2012). Pendidikan karakter merupakan landasan untuk mewujudkan visi pembangunan nasional yaitu untuk mewujudkan masyarakat berakhlak mulia, bermoral, beretika, berbudaya, dan beradab berdasarkan filsafah Pancasila. Pendidikan karakter pada usia dini sangatlah penting, karena menanamkan karakter pada anak maka diharapkan menjadi generasi penerus bangsa yang kuat dan berkarakter sesuai dengan nilai-nilai luhur Indonesia dan dapat mengatasi permasalahan kebangsaan saat ini.

Pada era globalisasi ini manusia juga dihadapkan pada kemajuan informasi, teknologi, komunikasi dan lain sebagainya kita sangat mudah apabila ingin mengetahui sesuatu yang terjadi dibelahan bumi lainnya. Di sinilah titik terberat bagi bangsa Indonesia, zaman mulai maju dan anak- anak bisa mendapatkan informasi dengan mudah. Maka dari itu, terjadilah krisis moralitas dan banyaknya kejahatan yang dipicu penggunaan dan pemanfaatan teknologi tidak sebagaimana mestinya. Pemerintah mengadakan pendidikan karakter bagi siswa-siswa untuk meminimalisir kesalahgunaan dan kesalah arti dalam perkembangan teknologi (Arostiyani 2013).

Susuai dengan kenyataan yang ada, anak-anak pada usia 3 tahun ke atas sudah mampu berinteraksi dan berkomunikasi dengan baik. Biasanya anak-anak pada masa ini sangat senang bicara dan menirukan. Pada usia 5-6 tahun anak-anak biasanya dimasukan oleh orang tua di Taman Kanak- kanak disini anak diajarkan bernyanyi bahkan boleh dikatakan $80 \%$ pendidikan yang diajarkan melalui media bernyanyi karena pada masa ini anak senang bernyanyi atau bermain dari pada belajar dengan serius. Pada masa keemasan ini anak-anak sangat cocok bila diajarkan tentang tata krama ataupun pendidikan karakter. Hal ini anak-anak masih sulit untuk memahami bahasa-bahasa kiasan, apalagi banyak anak yang apabila diberi tahu akan membantah dan melawan. Oleh karena itu, penulis mencoba meneliti tentang pendidikan karakter anak usia dini melalui media lagu anak-anak. Dengan lagu anak-anak yang menggunakan grafis digital diharapakan anak-anak akan senang dalam mempelajarinya, karena pendidikan karakter juga dapat disatukan dengan pelajaran bernyanyi melalui syair atau lirik lagu yang dinyanyikan.

Lagu anak-anak yang akan kami kaji yaitu menggunakan music video grafis digital. Grafis digital yang memvisualisasikan karakter, situasi, dan emosi. Saat ini sebagian besar anakanak sangat menyukai video musik yang dapat dikatakan animasi. Dahulu animasi hanya dibuat untuk film tetapi sekarang sudah merambah menjadi karakter dalam sebuah lagu.

\section{METODE PENELITIAN}

Metode penelitian yang digunakan penulis adalah metode kualitatif, dengan menggunakan dan mengkaji data-data yang berasal dari artikel dan penelitian kualitatif juga dikenal tata cara pengumpulan data lazim, yaitu melalui studi pustaka dan studi lapangan. Studi pustaka (berbeda dengan Tinjauan Pustaka) dilakukan dengan cara mengkaji sumber tertulis seperti dokumen, laporan tahunan, peraturan perundang, dan diploma/sertifikat (Dwiyanto 2002).

Sumber penelitian ini ialah hasil analisa penulis dalam menganalis objek yaitu akun youtube "Lagu Ana-anak". Analisa dilakukan secara mandiri, dengan melihat hasil media dari akun itu sendiri, mengandalkan elemen-elemen desain yang ada pada setiap hasil akhir suatu media.

Subjek dari penelitian ini adalah orang-orang yang menggunakan keterampilan mereka untuk menciptakan suatu gagasan, dengan membuat kata-kata yang dapat menarik perhatian orang lain, untuk mendapatkan tujuan mereka. Subjek penelitian merupakan orang yang diminta untuk memberikan keterangan tentang suatu fakta atau pendapat. Subjek lain yang ada 
dipenelitian ini ialah peneliti sendiri, karena peneliti terlibat secara langsung kedalam penelitian ini, peneliti yang menemukan masalah, dan peneliti juga yang menyelesaikan masalah.

\section{HASIL DAN PEMBAHASAN}

Belajar adalah suatu kata yang sudah akrab dengan semua lapisan masyarakat. Bagi pelajar atau mahasiswa kata "belajar" merupakan kata yang tidak asing. Bahkan merupakan suatu aktivitas yang tidak terpisahkan dari keseharian kita. Para ahli mengemukakan rumusan yang berlainan sesuai dengan bidang keahlian mereka masing-masing. Tentu saja mereka mempunyai alasan yang dapat dipertanggungjawabkan secara ilmiah. Belajar adalah berusaha memperoleh kepandaian atau ilmu. Belajar adalah serangkaian kegiatan jiwa raga untuk memperoleh suatu perubahan tingkah laku sebagai hasil dari pengalaman individu dengan lingkungannya yang menyangkut kognitif, afektif, dan psikomotorik. Belajar merupakan suatu proses yang kompleks yang terjadi pada diri setiap orang sepanjang hidupnya. Proses belajar itu terjadi karena adanya interaksi antara seseorang dengan lingkungannya. Jadi seseorang yang telah melakukan aktivitas belajar akan memperoleh perubahan dalam dirinya berupa pemilikan pengalaman baru yang belum pernah didapat sebelumnya. Pembelajaran adalah suatu kombinasi yang tersusun meliputi unsur-unsur manusiawi, material, fasilitas, perlengkapan, dan prosedur yang saling mempengaruhi mencapai tujuan pembelajaran. Manusia terlibat dalam sistem pengajaran tersendiri dari siswa, guru, dan tenaga lainnya, misalnya tenaga laboratorium. Material, meliputi buku-buku, papan tulis, alat tulis, fotografi, slide dan film, audio dan video tap, audio visual, juga komputer. Prosedur, meliputi jadwal dan metode penyampaian informasi praktik, belajar, ujian dan sebagainya (Diartono 2013).

Anak Usia Dini adalah makhluk unik yang memiliki karakteristik dan kebutuhan berbeda-beda. Anak usia dini adalah anak berusia 0-8 tahun yang memiliki berbagai potensi genetik dan siap untuk ditumbuh kembangkan melalui pemberian rangsangan. Pada masa ini anak mengalami masa keemasan (the golden age) yang merupakan suatu masa di mana anak mulai peka atau sensitif untuk menerima berbagai rangsangan. Di kelompok bermain, anak akan dididik dan dilatih berbagai bidang pengembangan pembisaaan yang meliputi moral, nilai-nilai agama, sosial, emosional dan kemandirian. Pengembangan KBM yang meliputi bahasa, kognitif dan fisik motorik. Salah satu aspek yang perlu dikembangkan dalam hal ini adalah aspek kognitif. Pengembangan kognitif dapat diperoleh melalui kegiatan berhitung, membilang, mengelompokkan, mengenal bentuk, mengenal konsep, angka dan bilangan.

Bidang pengembangan kognitif merupakan salah satu materi yang sulit dipahami oleh anak terutama dalam pengenalan konsep warna. Sebagai seorang guru hendaknya pandai-pandai memilih strategi pembelajaran yang tepat untuk mengatasi masalah tersebut. Pemberian materi oleh guru dengan menggunakan alat peraga ataupun media belajar bertujuan agar anak lebih mudah memahami materi yang diberikan. Di samping itu, pemilihan strategi mengajar perlu juga diperhatikan sebagai penentu keberhasilan suatu proses belajar mengajar.

Peran media dalam komunikasi pembelajaran di Kelompok Bermain semakin penting artinya mengingat perkembangan anak pada saat itu berada pada masa konkret. Salah satu prinsip pembelajaran di $\mathrm{KB}$ adalah kekonkretan, artinya anak diharapkan dapat mempelajari sesuatu secara nyata.

Selama ini dalam pembelajaran sehari-hari metode yang digunakan adalah metode ceramah dan pemberian tugas. Metode tersebut membuat anak menjadi pasif yaitu hanya mewarnai apa yang diberikan oleh guru, sehingga hasil yang diperoleh anak menjadi kurang optimal. Pembelajaran melalui media audio lagu-lagu yang diterapkan pada Anak Usia Dini tentunya dapat menstimulasi kecerdasan mereka, misalnya kecerdasan kognitif mengenai pemahaman konsep warna.

Dalam hal pembelajaran, komputer yang berbasiskan multimedia dimanfaatkan sebagai media perantara untuk mencapai tujuan pembelajaran tersebut. Dengan memanfaatkan perangkat multimedia maka seorang siswa tidak perlu bersusah-susah didalam mempelajari sesuatu seperti halnya membaca buku yang pada umumnya berkutat dengan teori an sich. Dengan menggunakan teknologi multimedia maka seorang pengguna dapat langsung 
berinteraksi dengan objek yang dipelajarinya. Dalam hal ini adalah memahami masalah yang diangkat karena media ini sudah dilengkapi dengan fasilitas audio visual sehingga fungsi pendengaran dan penglihatan dapat dioptimalkan. Disamping itu juga pengguna dapat mengulang (replay) jika terdapat ketidakpahaman pada pembelajaran yang telah terlewati.

Salah satu pemanfaatan multimedia dalam bidang pembelajaran adalah dengan membuat media belajar. Pembuatan media ini nantinya dikhususkan hanya pada penggunaan Photoshop untuk desain grafis sebagai objek pembelajaran. Photoshop digunakan untuk editing foto atau desain grafis yang akan ditampilkan dalam bentuk tampilan website, iklan, icon, lukisan, dan dalam tampilan-tampilan multimedia. Karena begitu pentingnya dalam membuat tampilan gambar atau desain grafis maka kelancaran dalam pengoperasian aplikasi ini sangat penting.

Pembelajaran berbasis multimedia merupakan jenis terobosan baru dalam zaman informasi yang menuntut segalanya berjalan dengan cepat. Pembelajaran dengan multimedia merupakan gabungan dari berbagai macam media yang terintegrasi yang secara bersama-sama menampilkan informasi, pesan, atau isi pelajaran. Konsep penggabungan ini dengan sendirinya memerlukan beberapa jenis peralatan perangkat keras yang masing-masing tetap menjalankan fungsi utamanya sebagaimana biasanya, dan komputer merupakan pengendali seluruh peralatan itu. Jenis peralatan itu adalah komputer, video kamera, video casette recorder (VCR), overhead projector, multivision (atau sejenisnya), CD player, campact disc. CD Player yang sebelumnya merupakan peralatan tambahan (exsternal peripheral) komputer, sekarang sudah menjadi bagian unit komputer tertentu. Kesemua peralatan itu haruslah kompak dan bekerja sama dengan menyampaiklan informasi kepada pemakainya. Informasi yang disampaikan melalui multimedia ini berbentuk dokumen yang hidup, dapat dilihat dilayar monitor atau ketika diproyeksikan ke layar lebar melalui overhead projector, dan dapat didengar suaranya, dilihat gerakannya (video atau animasi). Multimedia bertujuan untuk menyajikan informasi dalam bentuk yang menyenangkan, manarik, mudah dimengerti, dan jelas.

Informasi akan mudah dimengerti karena sebanyak mungkin indera, terutama telinga dan mata, digunakan untuk menyerap informasi itu. Bentuk informasi grafis, video, animasi, diagram, suara, dan lain-lain dengan mudah dapat dihasilkan dengan mutu yang cukup baik. Misalnya, video kamera berfungsi merekam video yang diinginkan kemudian ditransfer dan digabungkan dengan animasi, grafik, dan teks yang dihasilkan oleh komputer. Teks, grafik, animasi, video, sudah banyak tersedia dalam compact disc. Misalnya, Encyclopedia Americana sudah direkam kedalam compact disc, yang apabila ditampilkan didalam komputer melalui CD drive komputer itu maka informasi yang ada dalam disc baik berupa teks, gambar grafik, dan lain-lain dapat diakses dan dipindahkan untuk digabung dengan informasi lainnya (Diartono 2013).

Berdasarkan uraian di atas peneliti mengadakan penelitian tentang "Analisis Pengenalan Lagu Anak-anak secara Grafis atau Multimedia". Subjek dari penelitian ini adalah akun youtube anak bangsa yang bernama "Lagu Anak-anak" yang menurut penulis sangat kreatif dalam grafis secara keseluruhan. Akun ini juga memperkenalkan lagu anak-anak yang jarang sekali untuk sekarang ini dinyanyikan oleh anak kecil seusianya. Mengingat juga bahwa perkembangan musik anak-anak sekarang kurang diminati oleh kalangan anak-anak karena banyaknya lagu yang tidak diperkenalkan ke anak itu sendiri. Diharapkan dapat memberikan informasi tentang bagaimana grafis pembelajaran saat ini secara menyeluruh melalui pendekatan DKV seperti warna, elemen, teks, dan lain-lain. 


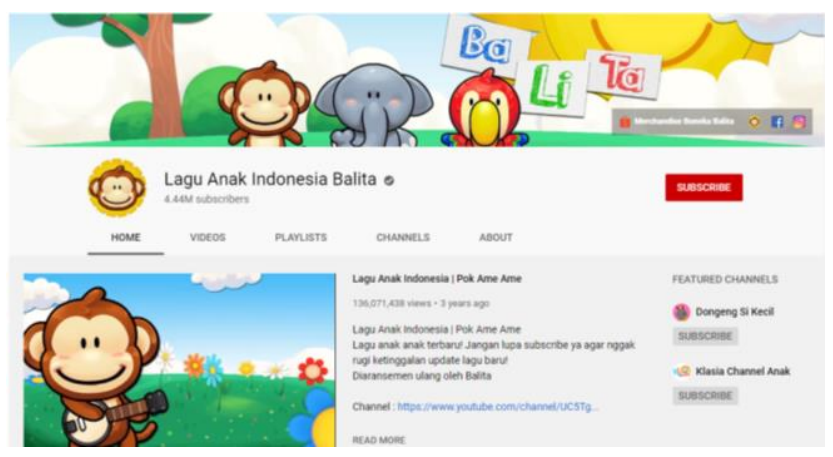

Gambar 1 Youtube Lagu Anak Indonesia Balita

Berdasarkan konten yang dibuat oleh akun tersebut, secara desain grafis akun tesebut telah memenuhi kriteria yang baik untuk pembelajaran anak-anak yang menontonnya. Berikut adalah analisis kami tentang konten akun youtube Lagu Anak Indonesia Balita secara grafis atau multimedia:

1. Warna

Warna adalah unsur seni rupa yang paling menonjol dalam karya seni. Bisa dibilang bahwa warna dalam karya seni mempunyai nilai paling tinggi dan biasanya suatu karya seni dinilai pada awalnya adalah dari segi warna. Nilai seni biasanya sih dilihat dari warnanya.

Warna memiliki kegunaan untuk menunjukkan gelap terang, karena ada berbagai jenis warna yang membuat efek cerah seperti warna kuning, biru muda, dan warna terang lain. Warna juga bisa melambangkan suasana perasaan, misalnya untuk menggambarkan suasana hati sedang sedih pemilihan warna bisa menggunakan warna warna pekat dan gelap. Warna juga bisa menunjukkan jauh dekat, perspektif dan sifat atau pun watak benda (Jadad.id, Tanpa Tahun).

Dalam ilmu desain, kriteria membuat desain yang ditujukan untuk anak-anak yaitu menggunakan warna yang cerah dan berwarna-warni. Seperti warna merah, kuning, dan hijau, semua warna yang cerah ada dalam kesatuan akan memberikan kesan yang menyenangkan. Hal ini dikarenakan anak-anak menyukai apapun yang menjadi perhatian penglihatannya. Desain yang tidak menggunakan warna cerah atau berwarna-warni kurang diminati oleh anak, biasanya warna yang flat digunakan untuk desain yang ditujukan untuk orang dewasa.

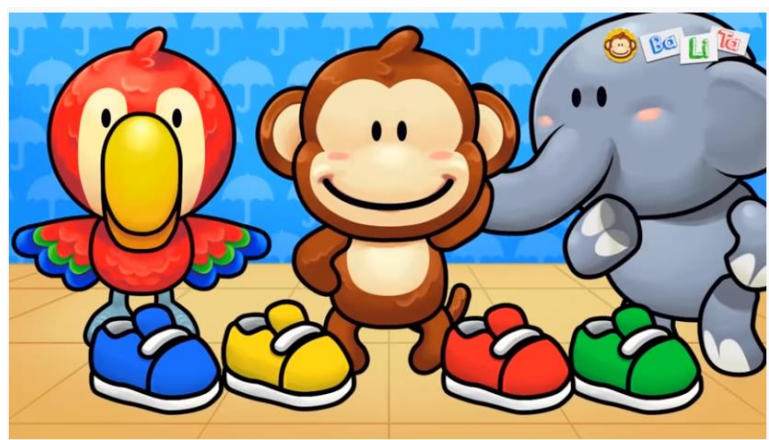

Gambar 2 Penggunaan Warna

Dalam pengemasan lagu di akun lagu anak-anak-anak ini sudah memenuhi kriteria desain yang baik yang sesuai dengan kalangan penontonnya. Warna-warna yang mereka tampilkan sangat beragam dan menarik para penontonnya, terbukti dari viewers mereka yang sangat banyak yang dapat mencapai jutaan penonton per videonya. Hal ini yang menjadi dasar penulis mengetahui bahwa lagu yang disajikan dengan animasi bergerak lebih banyak diminati oleh orang tua untuk menghibur anaknya. 
2. Karakter

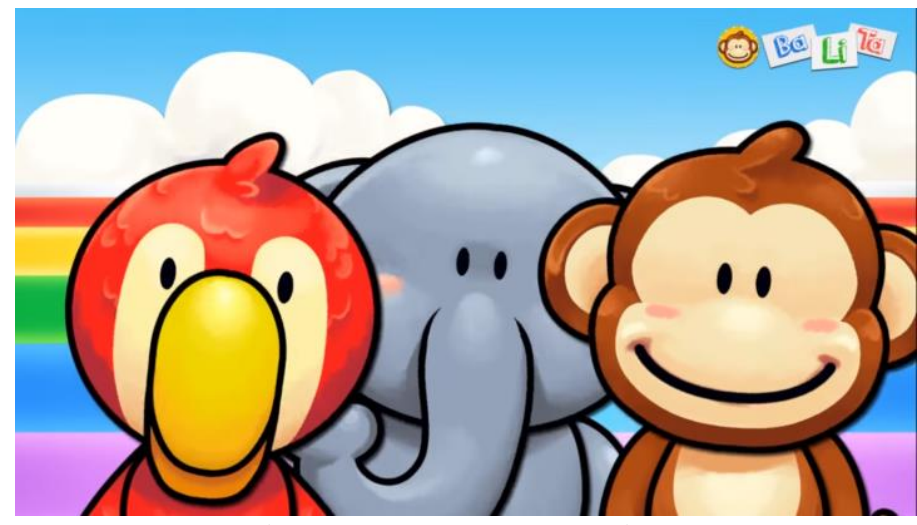

Gambar 3 Penggunaan Karakter

Karakter adalah watak, sifat, akhlak ataupun kepribadian yang membedakan seorang individu dengan individu lainnya. Atau karakter dapat dikatakan juga sebagai keadaan yang sebenarnya dari dalam diri seorang individu, yang membedakan antara dirinya dengan individu lain (Setiawan, 2021). Menurut W.B. Saunders, (1977: 126) (dalam Maemonah, 2015) menjelaskan bahwa karakter adalah sifat nyata dan berbeda yang ditunjukkan oleh individu, sejumlah atribut yang dapat diamati pada individu.

Dalam akun tersebut mempunyai maskot karakter Gajah sebagai "Baba", Burung Kakatua sebagai "Lili", dan Monyet sebagai "Tata". Jika disingkat namanya menjadi BaLiTa, karakter tersebut menggambarkan karakter yang ceria, pintar, dan menunjukkan persahabatan. Karakter yang ceria ini ditunjukkan dari gerakan animasi karakter yang bergerak melompat, berputar, dan menari. Karakter yang pintar ditunjukkan melalui syair/lirik lagu yang mengajak untuk melakukan dan mengajarkan hal baik atau hal baru. Dan yang terakhir adalah karakter yang menunjukkan persahabatan, terlihat dari ketiga maskot/karakter utama yang selalu melakukan hal apapun bersama.

3. Jenis Huruf/Font

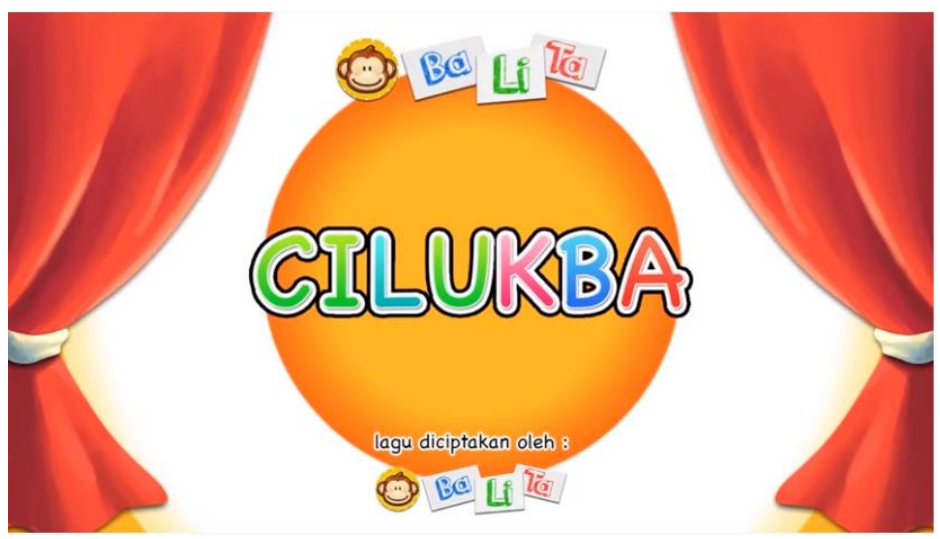

Gambar 4 Penggunaan Huruf

Jenis huruf/font merupakan tampilan grafis daripada sebuah teks. Ada sejumlah elemen berbeda yang dapat digunakan untuk membangkitkan emosi tertentu dalam desain. Namun, ada satu elemen penting desain yang sering diabaikan yang dapat memiliki dampak yang besar pada respons emosional audien, dan itu adalah font (Mulyawan, 2019).

Jenis huruf yang digunakan menurut kami sudah cukup bagus dan mudah dibaca dengan tambahan warna-warna yang cocok untuk dilihat anak-anak. Hal ini dikarenakan mereka menggunakan jenis huruf sans serif, yang mana jenis huruf seperti ini membuat 
gaya tulisan terlihat lebih simpel dan tentunya mudah untuk dibaca. Untuk menambahkan kesan saat dibaca, mereka menambahkan warna-warna yang beragam agar lebih masuk dalam video animasi. Font yang dipilih yaitu dengan huruf yang memiliki ujung yang tidak lancip/membulat di setiap ujungnya, memberikan kesan yang lembut dan tidak kaku.

4. Audio

Audio merupakan sinyal elektrik yang digunakan untuk membawa unsur bunyi, sehingga audio dalam komunikasi bercirikan suara. Istilah audio juga seringkali diartikan dengan sistem yang berhubungan dengan proses perekaman dan transmisi sistem pengambilan/penangkapan suara, amplifier, sambungan transmisi pembawa bunyi (dosen, 2021).

Musik yang digunakan adalah musik anak-anak berbahasa Indonesia yang sangat layak untuk didengar oleh pendengar dan pembaca agar menikmati saat menonton. Musik disini juga fungsinya sebagai pengenalan lagu anak-anak yang sudah di aransemen ulang agar mudah untuk ditiru dan diikuti. Musik yang mereka buat memberikan efek keceriaan bagi pendengarnya, ditambah lagi lirik yang mereka buat mudah dipahami oleh anak-anak.

5. Visual Tambahan

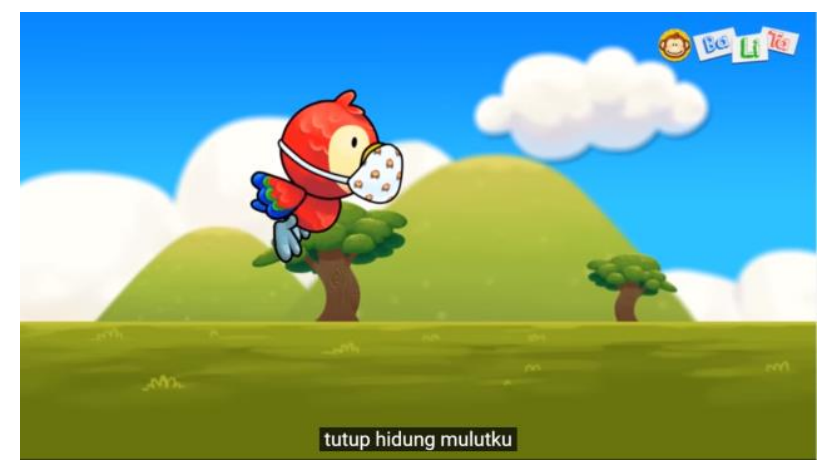

Gambar 5 Visual Tambahan

Visual tambahan terdapat pada gambar-gambar lain selain karakter dalam video. Seperti visual awan, pohon, mobil, rumah dan lain-lain. Dalam video visual tambahan yang ada sangatlah banyak dan juga beraneka ragam, yang menjadikan nilah tambah dalam penyajiannya, sehingga terlihat menarik perhatian dan mendukung pesan yang sampaikan.

\section{SIMPULAN}

Anak usia dini adalah anak yang berusia 0-8 tahun yang memiliki berbagai potensi genetik dan siap untuk ditumbuh kembangkan melalui pemberian rangsangan. Pada masa ini anak mengalami masa keemasan (the golden age) yang merupakan suatu masa di mana anak mulai peka atau sensitif untuk menerima berbagai rangsangan. Pengembangan KBM yang meliputi bahasa, kognitif dan fisik motorik. Salah satu aspek yang perlu dikembangkan dalam hal ini adalah aspek kognitif. Pengembangan kognitif dapat diperoleh melalui kegiatan berhitung, membilang, mesngelompokkan, mengenal bentuk, mengenal konsep, angka dan bilangan. Bidang pengembangan kognitif merupakan salah satu materi yang sulit dipahami oleh anak terutama dalam pengenalan konsep warna. Sebagai seorang guru hendaknya pandai-pandai memilih strategi pembelajaran yang tepat untuk mengatasi masalah tersebut.

Dengan adanya pengenalan lagu anak-anak secara grafis dan multimedia sangat efektif bagi anak-anak dalam hiburan sekaligus pembelajaran untuk cepat tanggap dan mengenal berbagai visualisasi grafis seperti warna, tulisan, audio, karakter dan lain sebagainya. Selama ini dalam pembelajaran sehari-hari metode yang digunakan adalah metode ceramah dan pemberian tugas. Metode tersebut membuat anak menjadi pasif yaitu hanya mewarnai apa yang diberikan 
oleh guru, sehingga hasil yang diperoleh anak menjadi kurang optimal. Pembelajaran melalui media audio lagu-lagu yang diterapkan pada Anak Usia Dini tentunya dapat menstimulasi kecerdasan mereka, misalnya kecerdasan kognitif mengenai pemahaman konsep warna.

\section{DAFTAR PUSTAKA}

Arostiyani, D. (2013). Pemanfaatan lagu anak-anak sebagai media pendidikan karakter di Taman Kanak-Kanak Aisyiyah Desa Linggapura Kecamatan Tonjong, Brebes (Doctoral dissertation, Universitas Negeri Semarang).

Diartono, D. A. (2008). Media pembelajaran desain grafis menggunakan photoshop berbasis multimedia. Dinamik, 13(2).

dosen. (2021). Pengertian Audio, macam-macam dan contohnya. https://www.dosentekno.com/teknologi/pengertian-audio-macam-macam-contohnya/

Dwiyanto, D. (2002). Metode kualitatif: Penerapannya dalam penelitian. Diakses dari: https://www. academia. edu/download/45555425/metode_kualitatif_penerapannya_ dalam_penelitian.

Jadad.id (Tanpa Tahun). Pengertian warna: Macam jenis dan kode warna. https://jagad.id/pengertian-warna-macam-jenis-dan-kode-warna/

Lagu Anak Indonesia Balita. Dikases dari https://www.youtube.com/channel/UC5Tg aUYKBtpnGipTVqDDuQ

Maemonah, M. (2015). Implementasi pendidikan karakter di madrasah/sekolah. Al-Bidayah: Jurnal Pendidikan Dasar Islam, 7(1).

Mulyawan, R. (2019). Mengenal pengertian font: Apa itu font family? sejarah, tujuan penggunaan, ukuran default dan contohnya serta perbedaannya dengan typeface! https://rifqimulyawan.com/blog/pengertian-font/

Saputra, W., \& Purnama, B. E. (2015). Pengembangan multimedia pembelajaran interaktif untuk mata kuliah organisasi komputer. Speed-Sentra Penelitian Engineering dan Edukasi, 4(2).

Setiawan, S. (2021). Pengertian karakter. https://www.gurupendidikan.co.id/pengertiankarakter/ 